
A C T A

Nadirah K. AL-SALIM ${ }^{1}$, A. M. Salim AL-DARAJI ${ }^{2}$

Fish parasitology

\title{
TRYPANOSOMA ARABICA SP. N. FROM THE FRESHW ATER FISH SILURUS TRIOSTEGUS HECKEL IN IRAQ ${ }^{x}$ \\ TRYPANOSOMA ARABICA SP. N. ZE SIODKOWODNEGO SUMA SILURUS TRIOSTEGUS HECKEL W IRAKU
}

\author{
bepartment of Fisheries and Marin Resources, College of Agriculture, \\ ${ }^{2}$ Marin Science Center Basrah University
}

\begin{abstract}
A new species of trypanosome from heart blood flim of Silurus triostegus Heckel is found. It is one of four species recorded and described from Al-Hammar marsh, North West of Basrah City. Comparision between the newly found species and that of the exitting species is given.

The newly found trypanosome is denoted as Trypanosome arabice sp. n. It is the first trypanosome to be recorded and described from the family Siluridoe in Iraq.
\end{abstract}

\section{INTRODUCTION}

Trypanosomes were common in both marine and freshwater fishes (Hoffman, 1970; Kudo, 1971; Duijn, 1973; Al-Salim, 1980). Few new species of trypanosome has been recorded and described in İraq (Warsi and Fattohy, 1976; Fattoy, 1978; Aljaffry and Rahemo, 1982; Al-Salim, 1985; Al-Jaffry, et al, 1988; Al-Salim and Al-Daraji, in press).

The present paper described a new species of trypanosome, Trypanosoma arabica $s p . n$. from the heart blood smear of a freshwater fish Silurus triostegus Heckel, 1843 collected from Al-Hammar marsh, North West of Basrah City. It is the first trypanosome to be recorded from family Siluridae in Iraq.

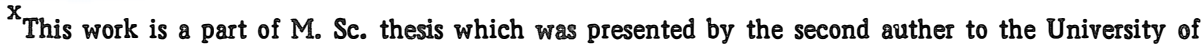
Basrah, 1986.
} 


\section{MATERIALS AND METHODS}

A total of 290 fish of five species (87 Barbus luteus (Heckel, 1843); 56 Aspius vorax Heckel, 1843; 42 Silurus triostegus Heckel, 1843; 70 Barbus sharpeyi Gunther, 1874 and 35 Liza abu Heckel, 1843 were collectea by seining and transported alive before examination. Fish were measured, sexed and thin blood smears were made from each fish. Blood were taken directly from the heart, blood smears were air dried, fixed in absolute alcohol, stained in Giemsa's stain, dried again and mounted in D.P.X. Mesurements were made by ocular lense micrometer under oil immersion objective. Photographs were taken by the aid of a photomicroscope.

\section{RESULTS}

A Silurus triostegus caught on November 1984 from Al-Hammer marsh was found infected with one organism of trypanosome.

Diagnosis: Monomorphic organism, C-shaped; body was elongated and big compairing with the other monomorphic species; flagellum relatively short; kinetoplast oval, relativeily small; nucleus reniform; cytoplasm granular, staing bluish-white, darker at both sides of body and vaculated; undulating membrane present; light infection.

Host: Silurus triostegus Heckel, 1843.,

Location: Blood plasma.

Locality: Al-Hammar marsh, North west of Basrah City.

Type material: One slide with the second auther.

The measurements in microne of one organism (Plate 1):

The total lenth including the free part of the flagellum $48.75 \mu$; body length $39 \mu$ body width at the center of the nucleus $2.4 \mu$ length of the free part of the flagellum $9.75 \mu$; nucleus is well developed, occupies the entir width of the parasite, reniform, stains dark pink in Giemsa's stain, its length $4.5 \mu$ and width $2.4 \mu$; distance from the nucleus to kinetoplast $16.45 \mu$; kinetoplast oval, its length $1.35 \mu$, and width $0.9 \mu$ and far from the posterior extremity by 1 nuclear indes (posterior extremity-anterior extremity), $1.19 \mu$; cytoplasm stains bluish-white in Giemsa'sstain, contains granules of different sizes and two large vacuoles, one of them located anterior to the nucleus and the other posterior, it contains few small vacuoles distributed over all the body and contains no myonemes; undulating membrane is. well developed and generally lies arround the outer margin and have eight undulation. 


\section{DISCUSSION}

Traditionally, new species of piscine trypanosomes were proposed on the basis of host (Lima, 1976; Mandal, 1975, 1977). Backer (1967) mentioned that the identification of trypanosomes from fish involves the host and its geographical location.

In mansural analysis the present parasit does not seem to resemble any of the known silurid trypanosomes or trypanosomes from other fish families.

The present parasite differs from the Asian species T. clariae var parva and T. clariae var magna described by Laveran and Mesnil (1912) from Clariae macrocephalus, the present type is intermediat in size between the two varieties.

The present parasite differs from T. gachuii reported by Misra et al. (1973) in its body length, free part of flagellum and it is monopraphic while $T$. gachuii dimorphic.

The only known species recorded from the catfish in Iraq was T. mystuii from the freshwater fish Mystus pelusius (Family: Bagridae) which was found by Al-Jaffery and Rahemo (1982). The present parasite differs from T. mystuii in several respects, such as monomorphism, its short flagellum, body length, host species and family.

In Iraq few monomorphic trypanosomes were found, $T$. acanthobramae from Acanthobrama marmid found by Warsi and Fattohy (1976) and T. basrensis from Aspius vorax found by Al-Salim and Al-Daraji (in press). The present parasite differs from both of them by its measurements, the location of the nucleus, length of the free part of the flagellum and host species as shown in Table 1.

It seems clear from the above comparision that no known trypanosome similar to the present form. It is therefore named as Trypanosoma arabica sp. $n$. having the characteristics given before.

Table 1

Average measurements of $T$. acanthobramae, $T$. basrensis and $T$. arabica

\begin{tabular}{|l|c|c|c|}
\hline & T. acanthobramae & T. basrensis & T. arabica \\
\hline & 25.89 & 21.98 & 39 \\
Body length & 20.37 & 14.59 & 9.75 \\
The free part of flagellum & 5.01 & 2.55 & 4.5 \\
Nucleus length & 2.71 & 0.85 & 2.4 \\
Nucleus width & 7.6 & 10.68 & 16.45 \\
Distance from nucleus to & 0.87 & 0.89 & 1.19 \\
kinetoplast & Acanthobrama & Aspius vorax & Silurus trio- \\
Nuclear index & marmid & & stegus \\
Fish host & & \\
\hline
\end{tabular}




\section{ACKNOWLEDGMENT}

The second author acknowledges the financial support from the University of Basrah.

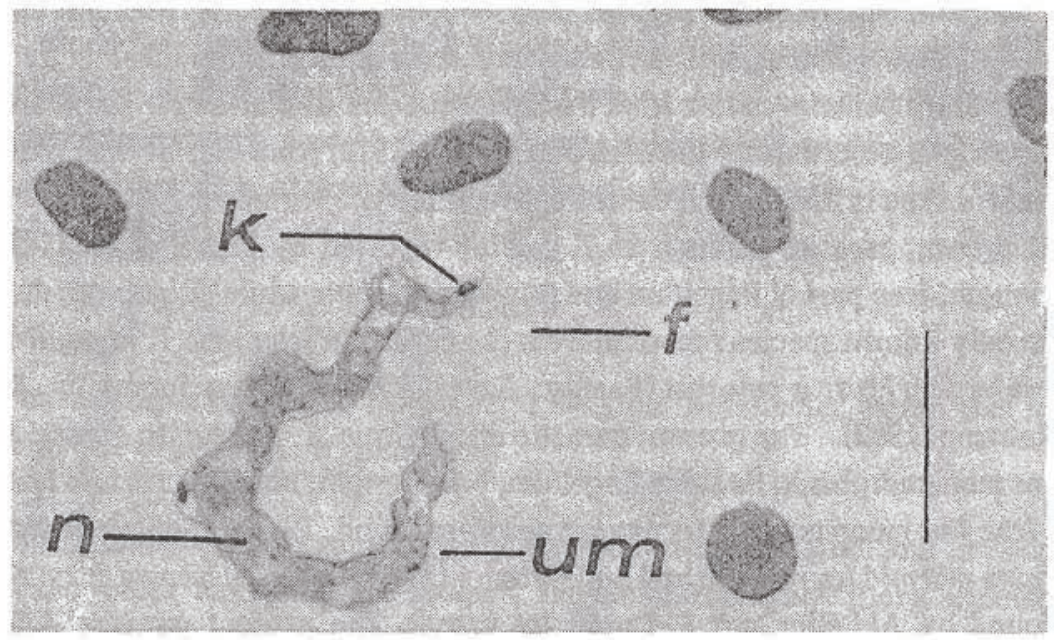

Phot. 1. Photomicrograph of Trypanosoma arabica sp. n. from the heart blood of a freshwater fish, Silurus triostegus Heckel, 1843

$\mathrm{k}$ - Kinetoplast um - Undulating membrane

$\mathrm{n}$-Nucleus $\quad \mathrm{f}$-Flagellum

Scale bar $=10 \mu \mathrm{m}$

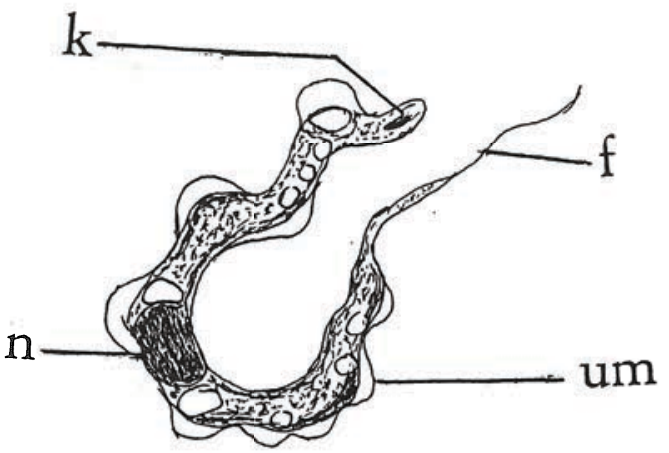

Phot. 2. Typanosoma arabica sp. $\mathrm{n}$ from the heart blood of a freshwater fish, Silurus triostegus Heckel, 1843

$$
\begin{gathered}
\mathrm{k}-\text { Kinetoplast } \text { um }- \text { Undulating membrane } \\
\mathrm{n}-\text { Nucleus } \mathrm{f}-\text { Flagellum } \\
\text { Scale bar }=10 \mu \mathrm{m} .
\end{gathered}
$$




\section{REFERENCES}

Al-Jafiry A. R. and Z. I. F. Rahemo, 1982: Trypanosoma mystuii Sp. N. from a freshwater Teleost fish Mystus pelusius Solander, in Iraq. J. Bio. Sci. 13, 1: 3-10.

Al-Jaffry A. R., N. M. Ali and N. E. Salih, 1988: Trypanosome garrae N. Sp. from the freshwater fish Garra rufa (Family: Cyprinidae). J. Biol. Sci. 19 Sppl.1.

Al-Salim N. Ko, 1980: Studies on some diseases of fish. Ph. D. thesis University College, Swansea.

Al-Salim N. K., 1985: Trypanosoma carasobarbi Sp. n. from a freshwater fish, Carasobarbus luteus (Hechel), 1843, (Family: Cyprinidae ) from Shatt Al-Arab river, Basrah, Iraq. J. Biol. Sci. 16 2: 205-215.

Al-Salim N. K. and S. A. Al-Daraji, (in press): Trypanosoma basrensis n. sp. from the freshwater fish, Aspius vorax Heckel, 1843 in Iraq. Academic Journal of Science.

Becker C. R., 1967: Trypanosome occidentalis sp. n. from freshwater Teleost in Washington State. J. Protozool. 14: 153-156.

Duijn C. V., 1973: Diseases of fishes, Iliffe Books, London,.

Fattohy Z. I., 1978: Trypanosoma neinavana sp. n. from the fish Barbus grypus, Heckel in Iraq, Curr. Sci. 47: 33-35.

Hoffman G. L., 1970: Parasites of North American freshwater Fishes. Univ. Calif. Press, Berkely.

Kudo R. R., 1971: Protozoology, Charles and Thomas, Publishing Springfield Illinois, U.S.A.

Laveran A. and F. Mesnil, 1912: Trypanosomes et Trypanosomiases, 2nd ed. Paris.

Lima D. F., 1976: Uma especie nova de tripanosoma na tainha (Mugil brasiliensis Agassiz, 1829) (Pisces Mugilidae), Revista brasileria de Biologia 36, 1: 167-9.

Mandal A. K., 1975: Two new trypanosomes from India freshwater Fishes. Angewandte parasitologia 16, 2: 87-93.

Mandal A. K., 1977: Trypanosoma choudhuryi sp. nov. from Tilapia mossambica (Peters). Acta Protozoologica 16, 1:1-5.

Misisa K. K., A. K. Chandra and A. Choudhury, 1973: Trypanosoma gachuii sp. n. from a freshwater Teleost Fish Ophicephalus Ham. Arch Protistenk 115: 18-21.

Warsi A. A. and A. I. Fattohy, 1976: Trypanosoma acanthobramae N. SP. from a freshwater fish, Acanthobrama marmid, Heckel (Family: Cyprinidae) from the river Tigris, Iraq. Curr. Sci. 45, 23: 838-839.

Nadirah K. Al-Salim, A. M. Salim Al-Daraji

TRYPANOSOMA ARABICA SP. N. ZE SEODKOWODNEGO SUMA SILURUS TRIOSTEGUS HECKEL W IRAKU

\section{STRESZCZENIE}

Nowy gatunek trypanosomy Trypanosoma arabica sp. n. został znaleziony we krwi suma Silurus triostegus Heckel, na bagnach Al Hammar na płn-zach. od miasta Basrah. Jest to pierwszy przypadek znalezienia trypanosomy u sumów w Iraku.

Author's addresses:

Received: 1990.06 .20

Nadirah K. Al-Salim

Department of Fisheries and Marine Resources

College of Agriculture

University of Basrah

Basrah, Irak (Iraq)

Salin. A. M. Al-Daraji

Marin Science Center

University of Basrah

Basrah, Irak (Iraq) 